\title{
Health challenges and access to health care among Syrian refugees in Jordan: a review
}

Wireen Dator, ${ }^{1}$ Hamzeh Abunab ${ }^{2}$ and Norenia Dao-ayen ${ }^{3}$

${ }^{1}$ Princess Nourah Bint Abdulrahman University, Riyadh, Saudi Arabia. ${ }^{2}$ Isra University, Amman, Jordan. ${ }^{3}$ Saint Louis University, Baguio City, Philippines. (Correspondence to: Hamzeh Y. Abunab: Habunab2015@gmail.com).

\begin{abstract}
Background: Syrian refugees in Jordan are currently facing difficulties in accessing adequate healthcare.

Aims: This study looked at the health conditions and barriers to accessing healthcare in Syrian refugees settled in Jordan.

Methods: Pubmed, CINAHL and Google Scholar were searched for published cross-sectional studies on the health status of Syrian refugees, specifically the prevalence of chronic diseases, communicable diseases, physical impairments, emotional and mental health problems, and barriers to health care. The terms searched were: Syrian refugee, health access barriers, health access, chronic diseases, communicable diseases/infectious diseases, physical impairment and mental health. The prevalence and $95 \%$ confidence intervals (CI) were calculated.

Results: The literature search yielded 265 articles, of which 8 were eligible for inclusion. The prevalence of the conditions assessed were: chronic diseases, $29 \%$ (95\% CI: 0.190-0.429); communicable diseases, $42.9 \%$ (95\% CI: 0.184-0.713); emotional and mental health problems, 32.9\% (95\% CI: 0.191-0.504); physical impairment, 14.4\% (95\% CI: 0.056-0.322). Financial issues were the greatest barrier to accessing health care for $66 \%$ (95\% CI: $0.449-0.823 \%$ ).

Conclusions: The health challenges of Syrian refugees are not just about chronic and acute diseases, injuries, or shortage of health resources or health disparities. It is a health burden that has become an economic, political and social crisis for the Jordanian government and its people, and measures and support to help Jordan continue to provide for refugees are needed.
\end{abstract}

Keywords: Refugees, Health resources, Health services accessibility, Health status, Syria, Jordan

Citation: Dator W; Abunab H; Dao-ayen N. Health challenges and access to health care among Syrian refugees in Jordan: a review. East Mediterr Health J. 2018;24(7):680-686. https://doi.org/10.26719/2018.24.7.680

Received: 03/10/16; accepted: 04/07/17

Copyright (c) World Health Organization (WHO) 2018. Some rights reserved. This work is available under the CC BY-NC-SA 3.0 IGO license (https:// creativecommons.org/licenses/by-nc-sa/3.o/igo).

\section{Introduction}

The 21st century has witnessed a growing number of conflicts in different parts of the world. As a result, the number of refugees seeking sanctuary in other countries is constantly increasing. The influx of refugees affects the political, socioeconomic and health circumstances of both the refugees and the host countries. The World Health Organization (WHO) and other United Nations (UN) and international aid agencies allocate resources and develop programmes to protect and sustain the security and welfare of refugees (1).

Conflicts remain the greatest threat to human development (2), and at the present time, the Middle East one of the regions most affected by conflicts (3). As a result, the region has experienced and continues to experience high levels of human displacement. Iraq, Syria and Yemen collectively represent more than $30 \%$ of the global displacement of people, including 2.7 million refugees, 13.9 million internally displaced people and an estimated 374200 stateless individuals. From Palestine alone, there are 5.1 million refugees registered in the UN Relief and Works Agency for Palestine Refugees in the Near East (3). Syria has faced an unprecedented level of displacement since 2011. At the end of 2015, more than 6.5 million Syrians were internally displaced and 4.6 million had sought refuge in different countries, including Jordan (4).

\section{Refugees in Jordan}

In the Middle East, Jordan is known for its modernized health care system, and Jordan's expenditure on health represents $7.2 \%$ of its gross domestic product. The Jordanian health care system includes the public sector, private sector and non-profit organizations (5). Jordan has remained one of the few stable countries in the Middle East despite the conflicts in the surrounding countries. Its geographical location makes Jordan an important gateway for many refugees from neighbouring countries. Jordan has a long history of dealing with refugee crises since the Arab-Israeli wars which started in 1948, the Gulf wars in 1991 and 2003 and the recent Syrian conflict since 2011 (6). According to UNHCR (Office of the UN High Commissioner for Refugees), the number of Syrian refugees who fled the country because of armed conflict exceeds the 655404 who are registered by the Jordanian Ministry of Interior and the 750000 who entered Jordan before the crisis, making the number of Syrians living in Jordan over 1.4 million (4). In addition to that, there are about 130911 Iraqi and 634182 Palestinian refugees $(7,8)$ who also sought shelter in Jordan. 
In 2014, Jordan's Ministry of Planning and International Cooperation reported that meeting the needs of Syrian refugees had severely affected Jordan's public finances and government expenditure on subsidies, public services and security. Refugees began to leave the camps to live in cities and towns within Jordan, and this has placed an extra burden on the basic services and infrastructure, and the resources the local communities $(9,10)$. Jordanian communities have borne the brunt of the influx of refugee with increased vulnerability to communicable diseases, compromised health services, and access to them, and increasing levels of morbidity, environmental issues, social problems.

\section{Aims of the study}

Refugees need various kinds of support including health care, education, infrastructure and resettlement resources and funding (11,12). Because of their circumstances, refugees may have poor health and face difficulties accessing health care. Lack of health insurance, and language and cultural differences are additional factors that contribute to their poorer health. This aim of this study was to evaluate the health condition of Syrian refugees in Jordan to identify their health challenges, specifically the prevalence of chronic diseases, communicable diseases, physical impairments, emotional and mental health problems, and barriers to health care, by a review of the available studies and reports.

\section{Methods}

\section{Study design}

Searches were carried out using MEDLINE (PubMed), CINAHL, Google Scholar databases with no restriction on the date of publication. The following terms, alone or in combination, were searched: Syrian refugees, health access barriers, health access, chronic diseases, communicable diseases/infectious diseases, physical impairment and mental health. Medical subject headings (MeSH) descriptors were used to index the content of the databases. The prevalence of the outcome measures was computed based on the findings reported in the selected study using the prevalence ratio and its confidence interval levels (CI) at 95\% CI.

\section{Study selection criteria}

Studies included in this review met the following criteria: 1) Externally displaced Syrian citizens in Jordan; 2) Outcomes - prevalence of communicable and noncommunicable diseases, physical impairment, emotional, mental health problems, and barriers to health care access; and 3) Study design - cross-sectional studies. Selected studies were evaluated using the quality assessment tool for cross-sectional studies of the Joanna Briggs Institute (13). The tool includes 8 questions assessing the following: clarity of inclusion criteria in the selected studies; detailed description of study subjects and setting; reliability and validity of measurements; objective, standard criteria used for measurement of the condition, identification of confounding factors; strategies used to deal with confounding factors; valid and reliable measurement of outcomes; and appropriateness of the statistical analyses used. Every item should be rated "Yes", "No", "Unclear", or "Not applicable" (13). The result of the appraisal is rated as "include", exclude" or "seek further information". Review articles, editorials and other publications that were not original research articles were excluded.

\section{Synthesis of main findings}

Data were abstracted using a standardized abstraction tool developed by the authors to include the following information: author's name, year of publication, study design, sample size and outcome measures obtained. The outcomes considered were: prevalence of communicable and noncommunicable diseases, physical impairment, emotional and mental health problems and barriers to accessing health care.

\section{Results}

The literature search yielded 265 articles (Figure 1) but only 8 studies were eligible for inclusion in the review (14-21). The general characteristics of the studies included are shown in Table 1 . The total number of respondents from the 8 studies included in this review is 2779 . The result of the quality assessment is shown in Table 2 .

\section{Outcomes measured}

A critical review done of the articles evaluated the health status of the refugees in terms of the prevalence of chronic diseases, infectious or communicable diseases, emotional and mental health problems, and physical impairments as outcomes that were statistically measured. Refugees were located in different parts of the country in both urban and rural areas of various governorates as designated by the Jordan government. As well as Amman, which hosts the largest urban refugee population, Irbid, Karak and Maan also have Syrian refugee populations $(14,17,18)$.

The prevalence of chronic diseases among Syrian refugees, was 29\% (95\% CI: 0.190-0.429). There were varying chronic conditions reported, however, the most frequently reported were hypertension, diabetes, musculoskeletal conditions, cardiovascular diseases, metabolism conditions, arthritis and respiratory diseases. Acute illnesses were also prevalent to a certain extent $(14-18,20,21)$.

The prevalence of communicable or infectious disease was $42.9 \%$ (95\% CI: 0.184-0.713). The communicable diseases reported among the refugees included influenza and infectious diarrhoea. Influenza was the most prevalent communicable disease among the refugees and skin diseases were one of the less prevalent noncommunicable diseases $(14,16,17)$.

Emotional or mental health problems had a prevalence of $32.9 \%$ (95\% CI: $0.191-0.504 \%$ ). Different signs of psychological distress were observed in the refugees from the different camps. These signs included: stress, 


\begin{tabular}{|c|c|c|c|c|}
\hline No. & $\begin{array}{l}\text { Author } \\
\text { (reference number) }\end{array}$ & Design & $\begin{array}{l}\text { Sample } \\
\text { size }\end{array}$ & Measured outcomes \\
\hline 1 & Ay et al., 2016 (14) & Cross-sectional & 196 & $\begin{array}{l}\text { - Need for health care services } \\
\text { - Accessibility of health services } \\
\text { - Barriers to health services access }\end{array}$ \\
\hline 2 & Al-Fahoum et al., 2015 (15) & Cross-sectional & 120 & $\begin{array}{l}\text { - Adequacy of health care services } \\
\text { - Satisfaction with the provided services }\end{array}$ \\
\hline 3 & Basheti et al., 2015 (16) & Cross-sectional & 73 & $\begin{array}{l}\text { - Prevalence of psychological distress } \\
\text { - Perspectives of the provided health care services }\end{array}$ \\
\hline 4 & Doocy et al., 2016 (17) & Cross-sectional & 1550 & $\begin{array}{l}\text { - Access and utilization of health services among Syrian } \\
\text { refugees }\end{array}$ \\
\hline 5 & Doocy et al., 2015 (18) & Cross-sectional & 1550 & $\begin{array}{l}\text { - Prevalence of noncommunicable diseases } \\
\text { - Understanding of issues related to care-seeking for } \\
\text { noncommunicable diseases }\end{array}$ \\
\hline 6 & Gammouh et al., 2015 (19) & Cross-sectional & 765 & $\begin{array}{l}\text { - Prevalence of chronic disease } \\
\text { - Depression prevalence and comorbidity } \\
\text { - Medication shortages }\end{array}$ \\
\hline 7 & $\begin{array}{l}\text { Handicap International and HelpAge } \\
\text { International, } 2014(20)\end{array}$ & Cross-sectional & 429 & $\begin{array}{l}\text { - The number and needs of Syrian refugees living with } \\
\text { impairment, injury and chronic disease }\end{array}$ \\
\hline 8 & UNHCR, 2015 (21) & Cross-sectional & 411 & - Access to and utilization of key health services \\
\hline
\end{tabular}

\begin{tabular}{|c|c|c|c|c|c|c|c|c|}
\hline Item & $\begin{array}{l}\text { Ay et al., } \\
2016(14)\end{array}$ & $\begin{array}{l}\text { Al-Fahoum } \\
\text { et al., } 2015 \\
\quad(15)\end{array}$ & $\begin{array}{l}\text { Basheti } \\
\text { et al., } 2015 \\
\quad(16)\end{array}$ & $\begin{array}{l}\text { Doocy } \\
\text { et al., } \\
2016(17)\end{array}$ & $\begin{array}{l}\text { Doocy } \\
\text { et al., } 2015 \\
(18)\end{array}$ & $\begin{array}{l}\text { Gammouh } \\
\text { et al., } 2015 \\
(19)\end{array}$ & $\begin{array}{l}\text { Handicap } \\
\text { \& HelpAge } \\
\text { II, } 2014 \text { (20) }\end{array}$ & $\begin{array}{l}\text { UNHCR, } \\
2015 \text { (21) }\end{array}$ \\
\hline $\begin{array}{l}\text { Were the criteria for inclusion } \\
\text { in the sample clearly defined? }\end{array}$ & $\mathrm{Y}$ & $\mathrm{Y}$ & $\mathrm{Y}$ & $\mathrm{Y}$ & $\mathrm{Y}$ & $\mathrm{Y}$ & $\mathrm{Y}$ & $\mathrm{Y}$ \\
\hline $\begin{array}{l}\text { Were the study subjects and } \\
\text { the setting described in detail? }\end{array}$ & $\mathrm{Y}$ & $\mathrm{Y}$ & $\mathrm{Y}$ & $\mathrm{Y}$ & $\mathrm{Y}$ & $\mathrm{Y}$ & $\mathrm{Y}$ & Y \\
\hline $\begin{array}{l}\text { Was the exposure measured in } \\
\text { a valid and reliable way? }\end{array}$ & $\mathrm{Y}$ & UN & $\mathrm{Y}$ & $\mathrm{Y}$ & $\mathrm{Y}$ & $\mathrm{Y}$ & $\mathrm{Y}$ & $\mathrm{Y}$ \\
\hline $\begin{array}{l}\text { Were objective, standard } \\
\text { criteria used for measurement } \\
\text { of the condition? }\end{array}$ & $\mathrm{Y}$ & $\mathrm{Y}$ & $\mathrm{Y}$ & $\mathrm{Y}$ & Y & $\mathrm{Y}$ & Y & $\mathrm{Y}$ \\
\hline $\begin{array}{l}\text { Were confounding factors } \\
\text { identified? }\end{array}$ & $\mathrm{Y}$ & Y & Y & $\mathrm{Y}$ & $\mathrm{Y}$ & $\mathrm{Y}$ & Y & $\mathrm{Y}$ \\
\hline $\begin{array}{l}\text { Were strategies to deal with } \\
\text { confounding factors stated? }\end{array}$ & $\mathrm{Y}$ & $\mathrm{Y}$ & $\mathrm{Y}$ & $\mathrm{Y}$ & $\mathrm{Y}$ & Y & $\mathrm{Y}$ & Y \\
\hline $\begin{array}{l}\text { Were the outcomes measured } \\
\text { in a valid and reliable way? }\end{array}$ & $\mathrm{Y}$ & $\mathrm{Y}$ & $\mathrm{Y}$ & $\mathrm{Y}$ & $\mathrm{Y}$ & $\mathrm{Y}$ & $\mathrm{Y}$ & $\mathrm{Y}$ \\
\hline $\begin{array}{l}\text { Was appropriate statistical } \\
\text { analysis used? }\end{array}$ & $\mathrm{Y}$ & Y & Y & Y & $\mathrm{Y}$ & Y & Y & $\mathrm{Y}$ \\
\hline $\begin{array}{l}\text { Overall appraisal: Include }(\sqrt{ }) \text {, } \\
\text { Exclude }(\mathrm{X}) \text {, or seek further } \\
\text { info(?) }\end{array}$ & $\sqrt{ }$ & $\sqrt{ }$ & $\sqrt{ }$ & $\sqrt{ }$ & $\sqrt{ }$ & $\sqrt{ }$ & $\sqrt{ }$ & $\sqrt{ }$ \\
\hline
\end{tabular}

Legends: $\mathrm{Y}=$ Yes; $\mathrm{N}=\mathrm{No}$; UN= Unclear; $\mathrm{NA}=$ Not applicable.

anxiety, fear, anger, fatigue, lethargy, lack of motivation, feelings of hopelessness, depression, difficulty falling asleep or staying asleep, and having periods of terror or panic. Emotional or mental problems among the Syrian refugees were drawn from a psychological assessment conducted which revealed high a proportion of respondents suffering from one or more signs of distress. About a third of the refugees assessed suffered all 6 distresses. The majority of the refugees reported that psychological treatment and support were not needed despite the high prevalence of emotional or mental health problems $(14,15,19,20)$.

The prevalence of physical impairments was $14.4 \%$ (95\% CI: $0.056-0.322 \%$ ). This included functional limitations such as physical mobility, vision and hearing problems, and injuries of which $80 \%$ were sustained as a direct result of the war in Syria. Most of the injured 
people were male, around $25 \%$ were female; and a small percentage of children had also been injured. A number of disabled household members had received treatment or support-surgical treatment, rehabilitation, psychological support or assistive devices $(16,20,21)$.

Financial issues as a barrier to accessing health care was reported with a prevalence of $66 \%$ (95\% CI: $0.449-0.823 \%)$. These included cost of the medical services, medicines and transportation. Refugees in the camps have free access to health care services which are subsidized by the government and other international agencies collaborating on the welfare of refugees. On the other hand, the refugees who live outside the camps are treated like non-insured Jordanians. Both refugees in the camps and those outside the camps are reported to experience financial barriers. Refugees are burdened by out-of-pocket payments to cover the high costs of services, consultations and medications in private centres. The cost of transportation is one of the highest expenses for refugees seeking health services from health centres outside the refugee camps because the majority are located far from the camps $(14,17,19,20)$. The total prevalence of the transportation problems for refugees was $26.7 \%$ (95\% CI: 0.057-0.686\%) (14,17,21).

The unavailability of medicines and medical equipment was reported as a barrier to obtaining the health care needed with prevalence of $26.7 \%(95 \%$ CI: $0.070-0.638 \%)$. Refugees seeking consultations receive prescriptions but in most cases the prescribed medications were not obtained because the medicine was out of stock at the public facility or the family could not afford the cost of the medicine. Refugees also reported other structural barriers, such as a lack of specialist doctors in health centres, and the refusal of the health facilities or personnel to provide services. The lack of medical equipment was the least reported barrier $(14,17,21)$.

The level of awareness about the available health care services also was assessed in 4 studies. The assessment included the refugees' knowledge of the available health services such as UNHCR-supported facilities, free access to vaccination, and subsidized access to government primary health care. Lack of knowledge of the health services available to them was reported as barrier by $20.6 \%$ (95\% CI: $0.115-0.342 \%)$ of refugees $(14,15,17,21)$.

\section{Discussion}

Because of Jordan's long experience of hosting refugees, it has mechanisms in place to sustain the welfare of refugees in the country. Despite the enormous sociopolitical, environmental and economic burdens of handling refugees, Jordan has remained steadfast in its humanitarian commitment to refugees despite depletion of its resources and, to some extent, deprivation of its local population of government allocations $(8,9,14,15)$. The movement of Syrian refugees from their country began in 2011 and has continued unabated up to now. By the end of 2015, Syrians made up nearly $15 \%$ of the population in Jordan (8). Two main programmes were developed to respond to the Syrian crisis in Jordan-the Sixth Regional
Response Plan (RRP6) of UNCHR and the National Resilience Plan (NRP) of the government of Jordan (9).

\section{Health condition of Syrian refugees}

Despite access to health care, refugees are still burdened by diseases (17). The health challenges faced by refugees reflect in general the health conditions and trends in both Syria and Jordan, and, to some extent, across the world. The epidemiology of diseases in Syrian refugees mirrors that of many countries worldwide. The findings of this review show that Syrian refugees suffer from chronic diseases, communicable diseases, injuries, and mental and emotional problems (14-21). Chronic diseases like diabetes, hypertension, cardiovascular diseases and cancer are among the leading causes of mortality and morbidity globally (2). The high burden of these noncommunicable diseases are more complex and they often require specialist care (18). Syrian refugees suffer from the same chronic illnesses, and in most cases they were diagnosed while still in Syria. Even before the outbreak of war, Syria was known to have a high burden of noncommunicable diseases (18). Displacement of refugees from their own homes and their loss of resources have worsened their health conditions. Although the risk factors for these chronic diseases are mostly modifiable, refugees are more concerned with and focused on their survival than managing their chronic conditions. At the same time, their living conditions as refugees make them more vulnerable to different kinds of diseases, both chronic and acute, communicable and noncommunicable. Therefore, health services for health promotion and illness prevention should be intensified and provision of hospital and health centre services for acute care should be improved and widened. Promotion programmes improve health-seeking behaviour and increase knowledge about home treatments for minor illnesses such as upper respiratory infections. According to UNCHR partners, one of the most unmet gaps in the response to refugees is for noncommunicable diseases (21). The ability of refugees to manage simple illnesses by themselves can help improve their health status. Improvement in their health status will reduce the number of visits to health centres and hence decrease the financial expenditure of the health services. This, to some extent, should ease the financial problems of the refugees and the burden on the health care system in Jordan.

Experiencing war causes emotional and psychological stress. A number of nonpolitical organizations in Jordan, together with other groups and nongovernmental organizations, have programmes to help refugees with mental problems (15). Psychological problems when left unresolved can have dangerous consequences, and can escalate to anxiety, depression, violence, and suicide. The Jordanian government, and local nongovernmental and international organizations have included the mental health of the refugees in their recovery programmes. Programmes like the mental health and psychological support sub-working group manage clinical psychiatric care, and other groups are responsible for psychological support. 
The Jordanian government and UNCHR have laid out comprehensive programmes to tackle the health needs of refugees, but some refugees have failed to access these services because of their lack of knowledge about them. In 2013, the Community Health Task Group was created to raise community awareness of their rights to access health care, and what and where care services are available (22). The coverage of the community health programme, which targets both refugees and Jordanians, was initially implemented in the north of Jordan and has not been expanded across the country where thousands of other refugees are living (22).

\section{Health services and state policies}

Health services and access to them by refugees in Jordan are fairly well established. Jordan has one of the most advanced and well-resourced health care systems in the region, with both public and private sector services that can be used by Syrian refugees (5). Jordan has integrated refugees into their health system so they can use the public services in a similar way as Jordanians. Refugees who are registered under the Ministry of Interior in Jordan are provided with health care access and benefits in the governorate where they are settled in the same way as uninsured Jordanians (16).

International organizations like UNCHR also provide help for the refugees. Free health services and resources are available in the camps to help alleviate the financial burden on Jordan in meeting the health needs of the refugees. However, these are still not enough to cope with the health needs of the refugees and improve their health status, particularly as their numbers keep increasing (9). The Sixth Regional Response Plan of UNHCR involves intersectoral working groups in an organized, systematic and specialized delivery of services, which includes: cash assistance; education; food security; health, reproductive health and mental health services; nutrition; noncommunicable diseases; community health; non-food items; protection; child protection; sexual and genderbased violence; shelter; and WASH, which is responsible for water, sanitation and hygiene services. Health is one of the main components of both the UNCHR and Host Community Support Platform responses to the refugee crisis (9).

The Host Community Support Platform/National Resilience Plan was established in September 2013 to prevent the deterioration of development achievements in Jordan while tackling the refugee crisis. The effect of the Syrian refugee crisis has extended across communities all over Jordan but the Host Community Support Platform initially covered only northern Jordan, mainly Irbid, Mafraq, and Zarqa governorates; it will gradually expand geographically as the crisis in the northern area is resolved (9). The programme is a government initiative parallel to the Sixth Regional Response Plan of UNHCR.
In 2014, changes in the health care policies of the Ministry of Health on the access of health services by refugees required refugees to cover the costs of medicines and consultations, and this has greatly affected them (14). It has been reported that money is one of the main barriers for refugees to access health services, as well as the distance of clinics from their camps $(17,19,20)$. Although, the programmes of the Sixth Regional Response Plan of UNHCR provide cash assistance to Syrian refugees both in and out of the camps and to vulnerable Jordanian nationals, the financial burden is still reported as a barrier to health access despite the cash assistance.

\section{Conclusions}

The burden of the health challenges of the Syrian refugees in Jordan is not confined to the Syrians themselves. It is not just about chronic and acute diseases, injuries, shortages of health resources, or health disparities. It is a health burden that has become an economic, political and social crisis for the Jordanian government and its people Although the health conditions of the Syrian refugees are not the best, Jordan appears to have responded adequately to the burden of the Syrian refugee crisis and provided for the needs of the large number of refugees, while at the same time maintaining service standards for Jordanians and mitigating the effect of the influx of refugees into the country. The commitment of Jordan to the responsibility of hosting the refugees, particularly given that Jordan is not an economic power in the world, is admirable and worthy of reward. Yet, some of this burden should be assumed by the international community, at least with resources that will help support the initiatives of Jordan if the financial burden is too great to allow them to maintain these initiatives and continue to take in refugees.

It may also be beneficial to mobilize the refugees themselves to tackle health issues. The community organizing participatory action research model is a longterm strategy for implementing primary health care delivery in depressed and underserved communities; this could be used by the Jordanian government to empower refugees $(23,24)$. Using this model, refugee communities would be trained and organized to participate in their health care as a part of a larger effort. It would be a long-term process but, in view of the large number of the refugees, it could be a powerful, self-serving and empowering mechanism for the refugees that at the same time could augment the Jordanian government's refugee response programme. Finally, it is recommended to undertake a future systematic review alongside metaanalysis to capture the rising needs of Syrian refugees in Jordan.

\section{Funding: None.}

Competing interests: None declared. 


\section{Défis en matière de santé et d'accès aux soins pour les réfugiés syriens en Jordanie : analyse}

\section{Résumé}

Contexte : Les réfugiés syriens en Jordanie connaissent actuellement des difficultés pour accéder à des soins de santé adéquats.

Objectif : La présente étude a examiné les conditions sanitaires et les obstacles qui empêchent les réfugiés syriens établis en Jordanie d'accéder aux soins de santé.

Méthodes: Des recherches ont été effectuées dans les bases de données Pubmed, CINAHL et Google Scholar afin d'identifier des études transversales portant sur l'état de santé des réfugiés syriens, et plus particulièrement sur la prévalence des pathologies chroniques et des maladies transmissibles, des handicaps physiques, des problèmes émotionnels et de santé mentale, et les obstacles aux soins de santé. Les termes recherchés étaient les suivants : réfugié syrien, obstacles relatifs à l'accès à la santé, accès à la santé, pathologies chroniques, maladies transmissibles/ infectieuses, handicaps physiques et santé mentale. On a calculé les taux de prévalence et les intervalles de confiance (IC) à $95 \%$.

Résultats : La recherche dans la littérature a produit 265 articles, dont 8 admissibles à l'inclusion. Les taux de prévalence des affections évaluées étaient : $29 \%$ pour les maladies chroniques (IC à $95 \%$ : 0,190-0,429) ; 42,9\% pour les maladies transmissibles (IC à $95 \%$ : 0,184-0,713) ; 32,9\% pour les problèmes émotionnels et de santé mentale (IC à 95\% : de 0,191 à $0,504) ; 14,4 \%$ pour les handicaps physiques (IC à $95 \%: 0,056-0,322$ ). Les problèmes financiers constituaient le principal obstacle à l'accès aux soins de santé dans $66 \%$ des cas (IC à $95 \%$ : 0,449-0,823).

Conclusion : Les défis de santé auxquels sont confrontés les réfugiés syriens ne sont pas seulement liés aux pathologies chroniques et aiguës, aux traumatismes, à un manque de ressources en santé ou à des disparités en matière de santé. Il s'agit d'un fardeau de santé publique qui s'est transformé en crise économique, politique et sociale pour le gouvernement jordanien et sa population; aussi des mesures et une aide sont-elles nécessaires afin de permettre à la Jordanie de continuer à pourvoir aux besoins des réfugiés.

$$
\text { الخيرين داتور، حزة أبو ناب، نورينيا داو ايين على الرعاية الصحية بين اللاجئين السوريين في الأردن: مراجعة }
$$

$$
\text { الخلفية: يو اجه اللاجئون السوريون في الأردن حالياً صعوبات في الحصول على الرعاية الصحية الكافية. }
$$

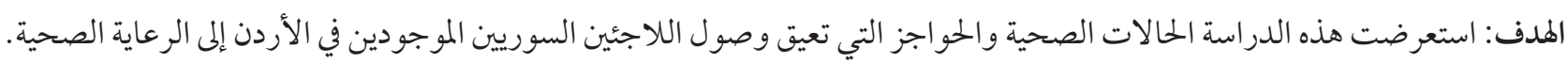

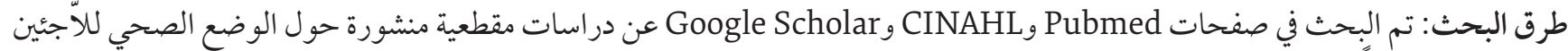

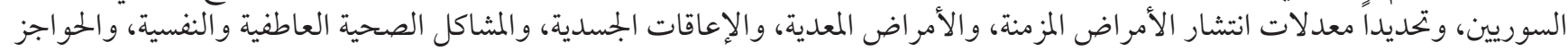

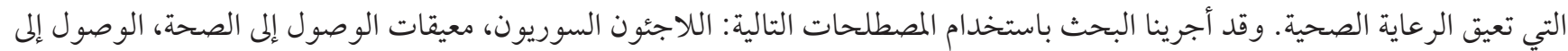

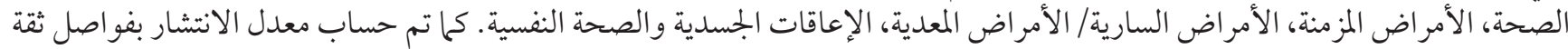

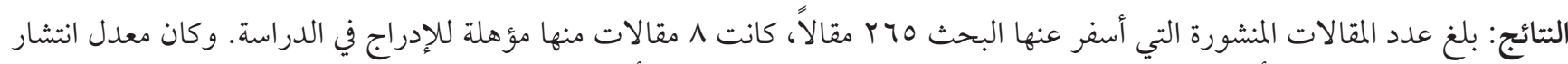

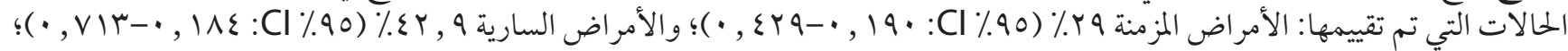

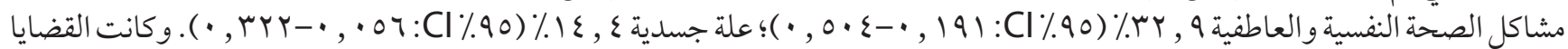

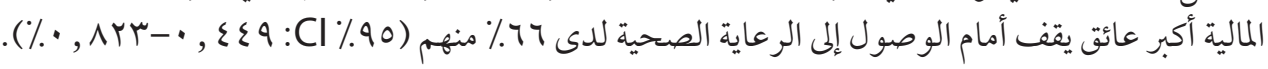

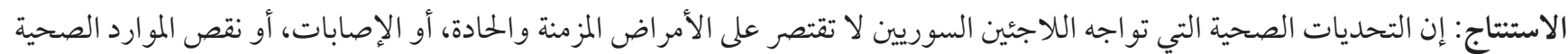

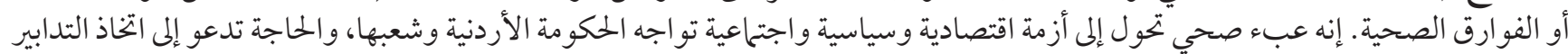
وتقديم الدعم لمساعدة الأردن على مو اصلة تقديم المساعدة للاجئين.

\section{References}

1. International Rescue Committee (IRC). Refugees and resettlement. 2016 (https://www.rescue.org/frequently-asked-questions-about-refugees-and-resettlement, accessed 28 September 2016).

2. The Millennium Development Goals report 2015. New York: United Nations; 2015 (http://www.un.org/millenniumgoals/2015_ MDG_Report/pdf/MDG\%202015\%20rev\%20(July\%201).pdf, accessed 6 March 2018).

3. Figures at a glance. Statistical yearbooks. UNHCR, the UN Refugee Agency (http://www.unhcr.org/figures-at-a-glance.html, accessed 20 August 2016). 
4. Registered Syrian refugees. Syria Regional Refugee Response. Inter-agency Information Sharing Portal. (http://data.unhcr.org/ syrianrefugees/regional.php\#_ga=1.137819891.2118143200.1471844483, accessessd12 December 2016)

5. Alloubani A, Abdelhafiz IM, Saleh AA. Relative and global health: a comparative study between healthcare systems of Jordan and France. World Health Popul. 2016;16(4):9-19. https://doi.org/10.12927/whp.2016.24671 PMID:27358015

6. Carrion D. Syrian refugees in Jordan: confronting difficult truths. London: Chatham House, Royal Institute of International Affairs; 2015.

7. Stevens D. Legal status, labelling, and protection: the case of Iraqi refugees in Jordan. Int J Refug Law. 2013;25(1):1-38. https://doi. org/10.1093/ijrl/eetoo1

8. Department of Public Statistics. the General Census of Population and Housing 2015. Amman, 2016.

9. Jordan response plan 2015 for the Syria crisis. Hashemite Kingdom of Jordan: Ministry of Planning and International cooperation; 2014 (http://www.jo.undp.org/content/dam/jordan/docs/Publications/JRP+Final+Draft+2014.12.17.pdf, accessed 30 Sep 2016).

10. Stave SE, Hillesund S. Impact of Syrian refugees on the Jordanian labour market. Geneva: International Labour Organization; 2015.

11. Koplan JP, Bond TC, Merson MH, Reddy KS, Rodriguez MH, Sewankambo NK, et al.; Consortium of Universities for Global Health Executive Board. Towards a common definition of global health. Lancet. 2009 Jun 6;373(9679):1993-5. https://doi. org/10.1016/So140-6736(09)60332-9 PMID:19493564

12. Lopez CE. Addressing health disparities in refugees. San Francisco: USF Scholarship Repository; 2014 (https://repository.usfca. edu/cgi/viewcontent.cgi?article=1060\&context=capstone, accessed 6 March 2018).

13. Joanna Briggs Institute reviewers' manual: 2016 edition. Joanna Briggs Institute. 2016 (https://reviewersmanual.joannabriggs. org/, accessed 1 Nov 2016).

14. Ay M, Arcos González P, Castro Delgado R. The perceived barriers of access to health care among a group of non-camp Syrian refugees in Jordan. Int J Health Serv. 2016 Jul;46(3):566-89. https://doi.org/10.1177/0020731416636831 PMID:26962004

15. Al-Fahoum AS, Diomidous M, Mechili A, Archangelidi O, Theodoromanolakis P, Mantas J. The provision of health services in Jordan to Syrian refugees. Health Sci J. 2015;9(2):2-7.

16. Basheti IA, Qunaibi EA, Malas R. Psychological impact of life as refugees: a pilot study on a Syrian camp in Jordan. Trop J Pharm Res. 2015 Sep 1;14(9):1695-701.

17. Doocy S, Lyles E, Akhu-Zaheya L, Burton A, Burnham G. Health service access and utilization among Syrian refugees in Jordan. Int J Equity Health. 201607 14;15(1):108. https://doi.org/10.1186/s12939-016-0399-4 PMID:27418336

18. Doocy S, Lyles E, Roberton T, Akhu-Zaheya L, Oweis A, Burnham G. Prevalence and care-seeking for chronic diseases among Syrian refugees in Jordan. BMC Public Health. 201510 31;15(1):1097. https://doi.org/10.1186/s12889-015-2429-3 PMID:26521231

19. Gammouh OS, Al-Smadi AM, Tawalbeh LI, Khoury LS. Chronic diseases, lack of medications, and depression among Syrian refugees in Jordan, 2013-2014. Prev Chronic Dis. 201501 29;12:E10. https://doi.org/10.5888/pcd12.140424 PMID:25633485

20. Hidden victims of the Syrian crisis: disabled, injured and older refugees (Report from Handicap International - Humanity \& Inclusion, HelpAge International). Reliefweb 9 April 2014 (https://reliefweb.int/report/syrian-arab-republic/hidden-victims-syrian-crisis-disabled-injured-and-older-refugees, accessed 5 August 2016).

21. UNHCR. At a glance: health access and utilization survey among non-camp refugees in Jordan. 2015.

22. Shteiwi M, Walsh J, Klassen C. Coping with the crisis: a review of the response to Syrian refugees in Jordan. Center for Strategic Studies. 2014 (http://jcss.org/Photos/635520970736179906.pdf, accessed 6 March 2018).

23. Wallerstein NB, Duran B. Using community-based participatory research to address health disparities. Health Promot Pract. 2006 Jul;7(3):312-23. https://doi.org/10.1177/1524839906289376 PMID:16760238

24. Minkler M, Wallerstein N, editors. Community-based participatory research for health: From process to outcomes. San Francisco: John Wiley \& Sons; 2011. 